IdeAs

Idées d'Amériques

$12 \mid 2018$

Le tourisme dans les Amériques

\title{
First Lessons from Donald Trump's Trade Undiplomacy
}

Jean-Baptiste Velut

\section{OpenEdition}

1 Journals

Édition électronique

URL : https://journals.openedition.org/ideas/4147

DOI : $10.4000 /$ ideas. 4147

ISSN : 1950-5701

Éditeur

Institut des Amériques

Référence électronique

Jean-Baptiste Velut, «First Lessons from Donald Trump's Trade Undiplomacy », IdeAs [En ligne], 12 I

2018, mis en ligne le 06 novembre 2018, consulté le 20 octobre 2022. URL : http://

journals.openedition.org/ideas/4147 ; DOI : https://doi.org/10.4000/ideas.4147

Ce document a été généré automatiquement le 20 octobre 2022

\section{(c) (i) (9)}

Creative Commons - Attribution - Pas d'Utilisation Commerciale - Pas de Modification 4.0 International - CC BY-NC-ND 4.0

https://creativecommons.org/licenses/by-nc-nd/4.0/ 


\title{
First Lessons from Donald Trump's Trade Undiplomacy
}

\author{
Jean-Baptiste Velut
}

1 "The return of isolationism", "the demise of multilateralism", "the end of globalization"... these alarmist headlines have dominated analyses of America's place in the world since the election of Donald Trump. This applies to the trade policy sphere, where Donald Trump's nationalist and protectionist discourse has strongly departed from the dominant free trade narrative of his predecessors. Yet, if America's retreat from multilateral and regional institutions is clear in many policy spheres - climate action, arms proliferation or foreign aid - the significance of the current diplomatic revolution is subject to great speculation in the trade policy sphere. This article analyzes the underlying logic, extent and possible repercussions of current transformations of US trade diplomacy, by assessing this strategy through the lens of the USMCA (U.S.-Mexico-Canada agreement) or NAFTA (North American Free Trade Agreement) negotiations.

\section{The logic of retrenchment}

2 While the dramatic decline in trade and investment in the aftermath of the financial crisis of 2008-2009 raised fears of a sustained period of "deglobalization," the second decade of the twenty-first saw the blossoming of a new generation of preferential trade agreements of unprecedented geographic and regulatory scope like the Transatlantic Trade and Investment Partnership (TTIP or TAFTA) and the Transpacific Partnership (TPP). Although inherently weakened by their democratic shortcomings, these new international economic regimes were deployed as an ambitious geopolitical strategy aimed at shaping global economic governance for the near future.

3 Today, the contrast between the strategic ambitions of the new generation of "mega" trade deals designed under the Obama presidency and the "renegotiating agenda" of the Trump administration with allies and rivals alike could hardly be sharper. Admittedly, the trade wars between the world's two largest economies could have 
potential economic effects far beyond the conclusion of TTIP or TPP. Yet, despite its economic significance, the US economic showdown with China incarnates a transactional approach akin to the renegotiation of NAFTA or the Korea-US FTA, that is more concerned with targeted sector gains than a broader geostrategic vision of global economic governance. What accounts for this downsizing of American ambitions? What is the legacy of these first two years and what are the perspectives for the second half of the Trump presidency?

4 To assess Donald Trump's trade diplomacy, one must first examine the logic behind the current political revolt against the free trade narrative. Is his criticism against America's "bad [trade] deals" merely a rhetoric tool aimed at manipulating his electoral base or is there any substantive evidence that America has granted overly generous concessions to its trading partners to preserve the benefits of the multilateral trade system?

5 To begin with, what might seem like a Trumpian revolution in foreign economic policy is, from a broader historical perspective, anything but new. In one form or another, Washington's emphasis on reciprocal trade has been a recurrent feature of American trade history from the first diplomatic steps of the early Republic to the ratification of the 1934 Reciprocal Trade Agreements Act, the 1980s trade conflicts with Japan and the debates surrounding China's WTO membership. Bearing in mind these historical precedents, this section considers two explanations for Donald Trump's anti-trade posture.

6 The first hypothesis puts the logic behind Trump's mercantilist approach to the test of trade economics by assessing whether the United States might indeed have granted unilateral market access to its trading partners to the detriment of its working class. This scenario echoes the notion of the "benevolent hegemon" according to which American foreign economic policy was subservient to its economic interests during the Cold War (as Senator Paul Tsongas (D, MA) famously said: "The Cold War is over; Japan won."). One way to assess the level of reciprocity between the US and its trading partners consists of comparing the US average tariff level with the rest of the world. Figures and 2 show average tariff levels in comparative perspective and reveals that the US is indeed one of the countries with the lowest tariff levels. Among the world's top four trading powers, the US has the lowest tariff average (Most-Favored Nation or MFN) for all products as well as for agricultural goods, and the lowest share of duties above $15 \%$ in both categories. This means that when it comes to MFN tariff barriers, the US economy provides greater access to other WTO members than the European Union, Japan and China - the latter having the high tariff levels among all for all categories.

Carte 1: World map of average MFN tariff levels

Source: WTO, 2018

IdeAs, 12 | 2018 


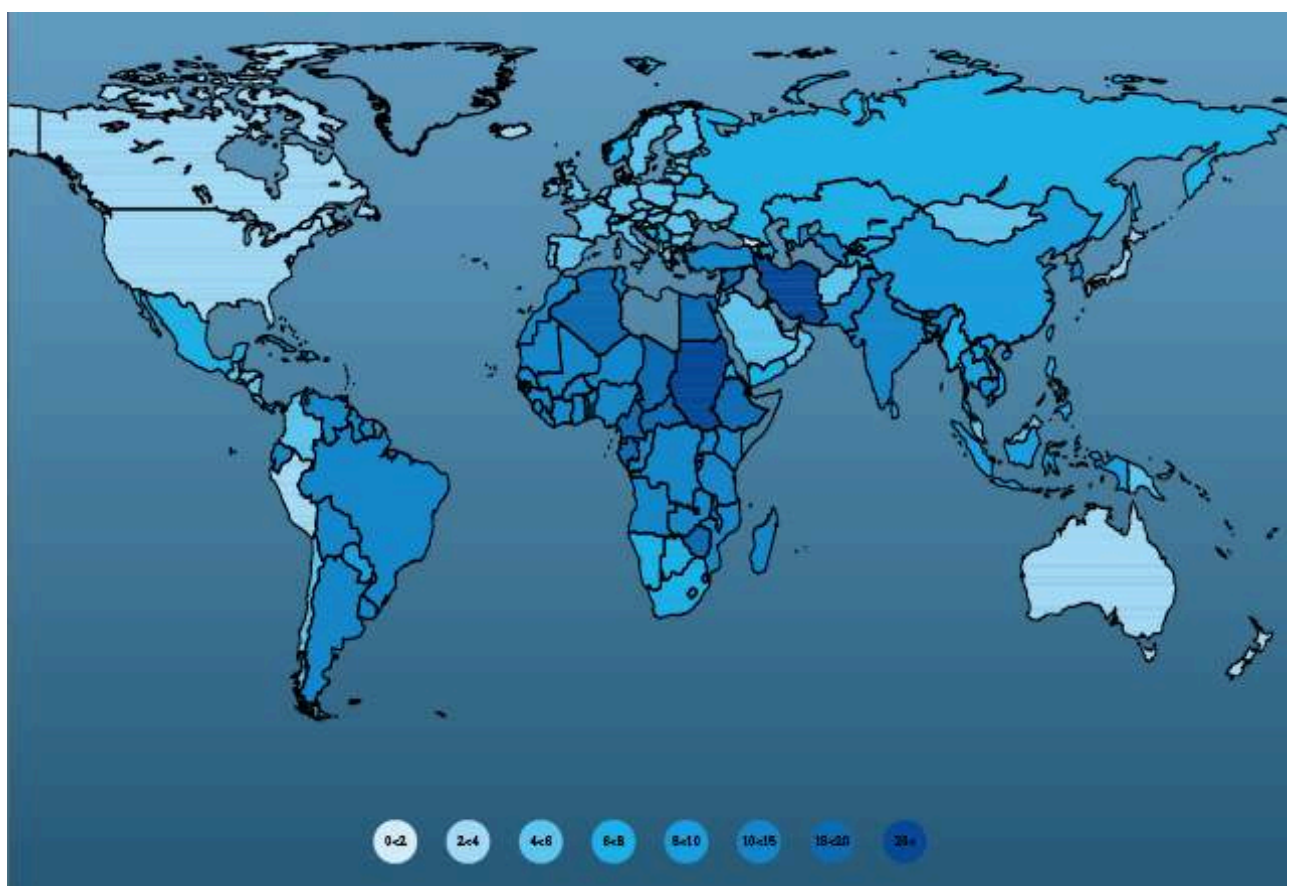

Figure 1: US tariff levels in comparative perspective

Top 4 trading powers

Source: WTO, 2018

\begin{tabular}{|l|l|l|l|l|}
\hline \multicolumn{2}{|l|}{} & \multicolumn{2}{|l|}{ ALL PRODUCTS } & \multicolumn{2}{l|}{ AGRICULTURE } \\
\cline { 2 - 5 } & Simple average* & Duties $>\mathbf{1 5}$ & Simple average* & Duties $>\mathbf{1 5}^{*}$ \\
\hline USA & 3.4 & 2.8 & 5.3 & 5.9 \\
\hline EU & 5.1 & 4.2 & 10.8 & 21.4 \\
\hline China & 9.8 & 15.1 & 15.6 & 37.2 \\
\hline Japan & 4 & 3.4 & 13.3 & 20.8 \\
\hline
\end{tabular}

7 Under other measures, however, the United States is not the naïve great power that Donald Trump portrays it to be. Figure 3 shows that Washington has made much greater use of its trade defense instruments than its trading partners to seek reciprocity. By the end of 2017, the US had implemented 324 anti-dumping measures ${ }^{1}$ as an importer, while it had faced four times fewer (74) non-tariff measures. The US number of (notified) anti-dumping measures was almost three times larger than that of the EU, four times that of China and forty-six times that of Japan. The picture was similar with regard to countervailing duties (CVD) ${ }^{2}$, with Washington showing by far the highest propensity to use countervailing measures (93 as of the end of December 2017) in great disproportion of the number of CVD its exporters face (5). 
Figure 2: US use of non-tariff measures in comparative perspective

Top 4 trading powers

Source: WTO, 2018

\begin{tabular}{|l|l|l|l|l|}
\hline & \multicolumn{3}{|l|}{$\begin{array}{l}\text { ANTI-DUMPING final } \\
\text { measures in effect in Dec. 2017 }\end{array}$} & $\begin{array}{l}\text { COUNTERVAILING MEASURES: final } \\
\text { measures in effect in Dec. 2017 }\end{array}$ \\
\cline { 2 - 6 } & As importer & As exporter & As importer & As exporter \\
\hline USA & 324 & 74 & 93 & 5 \\
\hline EU & 117 & 38 & 16 & 3 \\
\hline China & 87 & 603 & 5 & 80 \\
\hline Japan & 7 & 59 & n/a & n/a \\
\hline
\end{tabular}

Thus, while the American market has been relatively more open to its WTO trading partners, it has also been much more aggressive in its use of trade defense instruments, a mixed picture that contrast with Donald Trump's rationale that the United States has been taken advantage of (or "raped" in his own words). Moreover, this brief picture of reciprocity in international trade only focuses on tariff and non-tariff indicators. With regard to other provisions of trade agreements - from investment protection to intellectual property rules - there is strong evidence that Washington has had tremendous influence on the nature of the international trading system, giving a competitive edge to many of its high-tech firms, especially in the services sector where America remains by far the world's top exporter.

The second interpretation considers Donald Trump's protectionist retrenchment as a strategy to rally a large base of disgruntled white working-class voters. Although trade has in effect played a limited role in the rise of social inequality and the hollowing out of the American middle class ${ }^{3}$, blaming trade and globalization for America's woes has long helped to mobilize voters. This was the case when Democrats managed to regain control of the Congress by blaming Republicans for their support for the Dominican Republican-Central Free Trade Agreement (DR-CAFTA) during the 2006-midterm elections. The fact that NAFTA has haunted American politics for twenty-five years is also a sign of its political traction. This is a common interpretation of Trumpism that is only partly substantiated. Figure 1 shows that the districts that were the most affected by trade (as measured by allocation of Trade Adjustment Assistance) were also those where support for Donald Trump was particularly high.

Figure 3: Trade-dislocated workers strongly supported Donald Trump 
Figure 3. Communities most impacted by trade dislocation voted for Trump Share of communities voting Trump by level of trade dislocation

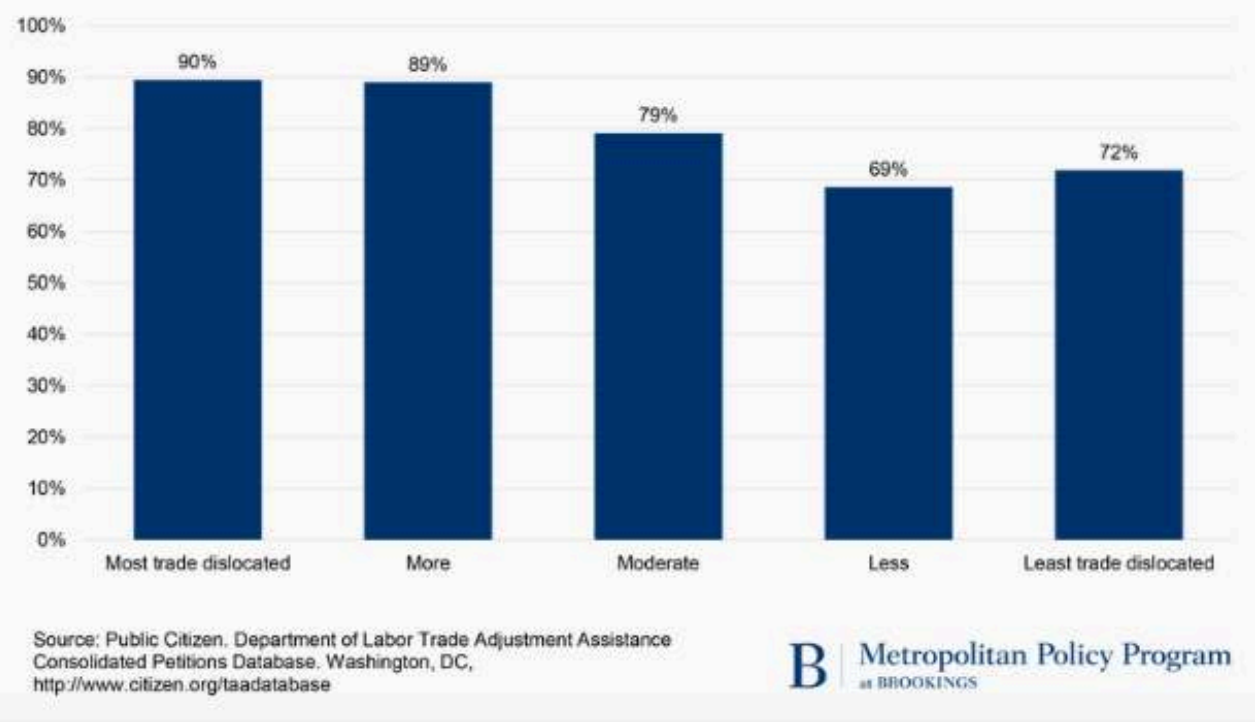

10 Yet despite common wisdom, the logic of Trump's economic nationalism cannot be reduced to a popular referendum against trade. For one, several studies have shown that racial resentment was a greater predictor of electoral support for Trump voters than economic anxiety. One survey conducted by the Washington Post showed that contrary to common representations, racial resentment drove economic anxiety, not the opposite ${ }^{4}$. These seemingly contrasting perspectives on the linkage between the backlash against globalization and political support for Donald Trump need not be irreconcilable. In fact, opposition to trade liberalization and racial attitudes have been central to the right wing of the Republican Party from the early 1990s debates on NAFTA to the controversies on the Permanent Normalization of Trade Relations with China. From this perspective, the central role of protectionism in Donald Trump's platform might be interpreted as a new Southern Strategy ${ }^{5}$, a form of coded language tapping racial prejudice against Latinos (NAFTA) and Asians (US-China trade wars), in turn feeding into the economic anxiety of so-called losers of globalization.

\section{From theory to practice}

11 These interpretations of Trumpian retrenchment raise two sets of questions for a first assessment of Trump's record: 1) Has the doctrine of America First helped rebalance the world economy to America's favor? 2) Has it started to address working class anxiety or merely stoked racial resentment? The NAFTA renegotiations constitute an important case study to address these questions and evaluate the practice of Donald Trump's trade diplomacy.

12 Before focusing on the content of US trade policy, it is important to draw the lessons from the atypical process under which these renegotiations took place, which culminated with the signature of the rebranded "U.S.-Canada-Mexico Agreement" on September $30^{\text {th }}, 2018$. When President Trump vowed to use a take-no-prisoner approach to renegotiate the "worst trade deal ever," he apparently meant it, as illustrated by the long series of threats, poisoned pills, insults and the divide-andconquer tactics that led to the temporary exclusion of Canada from trade negotiations. 
The first impression of one lobbyist best summarizes America's new "trade undiplomacy." According to him, US Trade Representative and chief NAFTA negotiator Robert Lighthizer began the negotiations "by putting the gun and the knife on the table," a posture that would characterize the negotiating style of the US administration until the conclusion of the talks.

Although the real-estate-magnate-turned-president kept his promises with regard to the trade negotiating process, the content of the new trade deal is far from a political revolution. With regard to market access, and despite Trumpian triumphism, there is little substance to assume that the USMCA brought greater reciprocity to North American relations. First, however politically unpalatable to Canadians, the concessions granted in the dairy sector have long been blown out of proportion by the Trump administration. According to a Brookings study, the estimated gains are expected to represent little more than $0.2 \%$ of total US dairy revenues ${ }^{6}$. While Canada granted additional concessions to US exporters in the agricultural (chicken, turkey, eggs and wine markets) and pharmaceutical sectors (extension of protection for biologic drugs) and raised its de minimis levels for cross-border shipments, the US tariff side deals in the auto industry increased quotas for duty-free imports for auto parts and vehicles, while the USMCA preserved the protection of Canadian cultural industries. The irony is that North American negotiators largely built upon the chapters that they had negotiated under the TPP that Mexico and Canada had adopted without the United States. In short, the rebranding of NAFTA aside, as far as market access is concerned, there is little evidence that the USMCA has "modernized" or "rebalanced" North American trade relations beyond what the TPP had accomplished. In the words of a trade commentator, NAFTA 2.0 is akin to TPP 0.8 .

The same conclusion goes for the new rules of origins and labor provisions contained in the new NAFTA. At first sight, the stricter rules of origins for the auto sector (from $62.5 \%$ under NAFTA to $75 \%$ under the USMCA) and new requirements that $40-45 \%$ of auto content be made by workers earning at least \$16 (far above Mexican manufacturing wages) are a creative attempt to bring back segments of the value chain back from Mexico ${ }^{7}$. Yet, in effect, many questions remain on the enforcement of these rules and on whether companies might seek to bypass wage requirements. Indeed, some analysts have argued that companies might prefer to pay relatively low MFN tariffs (outside of NAFTA) on auto parts to avoid disrupting their global value chains. As for the USMCA's labor chapter, experience shows that enforceability under the dispute settlement mechanism (like all post-NAFTA trade agreements) does not make it more likely for Washington to press for workers' rights protection. Thus, the second, and perhaps most important lesson from the USMCA is that it will do little to nothing to protect workers' rights or bring back manufacturing jobs to the United States; nor is it likely to reduce economic anxiety among American workers. Of course, the odds were against the Trump administration from the start, as NAFTA had always had a marginal effect on the decline of US manufacturing employment in the first place. Yet, in the light of its limited achievements on behalf of reciprocity and social justice, it is hard to believe that the new NAFTA was worth sacrificing the geostrategic benefits of TPP, or that its meager sectoral gains justified straining diplomatic relations with two key American trading partners. After two years of theatrics, it is time to call the new NAFTA by its real name: a political charade that, internationally, did considerable 
diplomatic damage and, domestically, will do little for American workers and may yet blow up in the face of its architects if Congress refuses to ratify it.

The third lesson of the USMCA - an apt acronym for political staging and theatrics - is that there is no coopting political extremism. This is a lesson that French President Macron has long learned after failing to rally Donald Trump behind the Paris Agreement or the Iran nuclear deal. In the case of NAFTA, neither Mexican President Nieto's pragmatic abnegation, nor Prime Minister Trudeau's clever outreach strategy to American states and business interests did anything to alter the course of negotiations. Perhaps the greatest victim of the USMCA was Canada's "progressive trade strategy" that sought to make trade policymaking more inclusive and accountable through the addition of chapters on indigenous rights and trade and gender, all of which were jettisoned under the dictates of American First. Thus, according to the new Gresham's law of international trade politics, Donald Trump's nationalist undiplomacy has not only replaced Barack Obama's ambitious geostrategic agenda but also aborted Justin Trudeau's inclusive trade policy framework. This should be a wake-up call for all partners considering a bilateral trade agreement with Washington, whether Japan, the EU or the United Kingdom. Despite the enthusiasm around the renewed transatlantic dialogue, the EU's "Trade for All Strategy" could be the next victim of US nationalist retrenchment and obliterate all the Commission's efforts to shore up support for a more sustainable form of trade liberalization. The USMCA shows that accommodation serves little purpose. This is a lesson that China has already drawn.

\section{NOTES}

1. According to the WTO, "Dumping is defined in the Agreement on Implementation of Article VI of the GATT 1994 (The Anti-Dumping Agreement) as the introduction of a product into the commerce of another country at less than its normal value. Under Article VI of GATT 1994, and the Anti-Dumping Agreement, WTO Members can impose anti-dumping measures, if, after investigation in accordance with the Agreement, a determination is made (a) that dumping is occurring, (b) that the domestic industry producing the like product in the importing country is suffering material injury, and (c) that there is a causal link between the two."

2. According to the WTO, countervailing duties are unilateral instruments designed to offset the impact of a country's subsidies. It may be applied by a member after an investigation and a determination that the criteria defined in the WTO's Subsidies and Countervailing Measures have been met.

3. For a discussion of the literature, see Jean-Baptiste Velut (2017). «(Dés) illusions du patriotisme économique Du «carnage américain » à «l'Amérique d'abord », Outre-Terre 50 (1), available at: https://www.cairn.info/revue-outre-terre-2017-1-page-126.htm

4. For a discussion, see German Lopez, "The past year of research has made it very clear: Trump won because of racial resentment", Vox, December 15, 2017, available at:

https://www.vox.com/identities/2017/12/15/16781222/trump-racism-economic-anxiety-study 
5. The Southern Strategy refers to Republicans' use of racial innuendos and coded language (e.g. "states' rights") to exploit white Southerners' resentment of the 1960 s civil rights reforms and incite them to defect from the Democratic Party.

6. Noll, Roger, Litan, Robert E., “Extra milk exports to Canada under Trump's rebranded NAFTA will be a drop in the bucket," October 8, 2018, available at: https://www.brookings.edu/blog/upfront/2018/10/08/extra-milk-exports-to-canada-under-trumps-rebranded-nafta-will-be-a-dropin-the-bucket/

7. Rules of origins are the criteria that determine where a product is made. Under the new NAFTA, $75 \%$ of a car content has to be produced in North America for it to qualify to preferential tariffs.

\section{AUTEUR}

\section{JEAN-BAPTISTE VELUT}

Maître de Conférences en Civilisation Américaine à l'Université Sorbonne Nouvelle - Paris III.

jean-baptiste.velut@univ-paris3.fr 